\title{
Religion of the Evenki: History and Modern Times
}

\author{
Yulia S. Zamaraeva*, Vladimir S. Luzan, \\ Svetlana V. Metlyaeva, Natalia N. Seredkina*, \\ Natalia P. Koptseva, Antonina I. Fil'ko \\ and Mikhail Ya. Khrebtov \\ Siberian Federal University \\ 79 Svobodny, Krasnoyarsk, 660041, Russia
}

Received 06.11.2018, received in revised form 30.04.2019, accepted 08.05.2019

The article attempts to reveal the transformation of the role of religion in preserving the traditional way of life of the Evenki ethnos from 1930s to 2000s in the northern regions of the Krasnoyarsk Krai, as well as its reflection in the education system and in traditional culture (folklore, visual arts, decorative and applied art). The article notes that the analysis of domestic and foreign studies of the culture and religion of the Evenki confirms the validity of appealing to an interdisciplinary type of research. The subject of the research is the traditional and non-traditional religious movements embodied in the culture and life of the Evenki ethnos. Observation, analytical-descriptive method, including the analysis of individual elements of the development of the Evenk traditional culture, followed by generalization of the data, as well as comparative historical and dialectical methods are used to solve the research problems. Moreover, among the main research methods, philosophical and art history analysis of art works of the Evenki is actively used. The conclusion indicates general outputs and tendencies characterizing the current state of the embodiment of religious trends in culture, education and everyday life of the Evenki ethnos.

Keywords: Evenk Municipal District, small-numbered indigenous people of the North, the Evenki, religion, folklore, art culture.

The reported study was funded by JSC "Vostsibneftegaz" according to the research project: "Revival of the Evenk's Language: Creation of the first Evenks digital audio library".

Research area: culturology.

Citation: Zamaraeva, Yu.S., Luzan, V.S., Metlyaeva, S.V., Seredkina, N.N., Koptseva, N.P., Fil'ko A.I., Khrebtov, M. Ya. (2019). Religion of the Evenki: history and modern times. J. Sib. Fed. Univ. Humanit. soc. sci., 12(5), 853-871. DOI: 10.17516/1997-1370-0428.

(C) Siberian Federal University. All rights reserved

* Corresponding author E-mail address: NevolkoN@yandex.ru; rybka08@bk.ru

ORCID: 0000-0003-1299-6741 (Zamaraeva); 0000-0002-0049-9417 (Metlyaeva); 0000-0003-3910-7991 (Koptseva); 0000-0002-2787-423X (Fil’ko)

This work is licensed under a Creative Commons Attribution-NonCommercial 4.0 International License (CC BY-NC 4.0). 


\section{Introduction}

Currently religion of indigenous peoples is of particular interest among researchers. Both their traditional beliefs (Cox, 2016) and the relationship between religion and society (Geertz, 2017) are being studied. A.F. Anisimov, V. A. Vasilevich, V.A. Togolukov, G.F. Miller, and N.A. Baskakov have been engaged in the study of the Evenki religious worldview. Scientists devote their work to a wide range of issues. The ideas of the Evenki about the soul, totemistic beliefs, the decomposition of ancient ancestral cults, the origin of shamanism, and others are considered. Among foreign researchers studying the Evenk religion, we can single out the works of D.G. Wilson and D. Brandišauskas. D. G. Wilson in his research considers the Evenk shamanism as a special form of discipleship (Wilson, 2013). D. Brandišauskas addresses the Evenki's perception of the alien and how the alien (especially the state system) is conceptualized through the prism of their beliefs (Brandišauskas, 2018).

Our research interest is focused on the analysis of the Evenk religion in the context of its historical development and the manifestation of the religious picture of the world in art culture.

\section{Methods}

The main methods of the study were making photos and analysing archival documents of the municipal state institution "Evenk Archive" of the Evenk Municipal District of the Krasnoyarsk Krai, expert interviews with carriers of the Evenki culture and specialists (during the field expedition by researchers and students of the department of cultural science of Siberian Federal University, Tura settlement in 2017); philosophical and art history analysis of graphic and pictorial works of masters of the Evenki art school, works of decorative and applied art of the Evenki.

\section{Discussion}

\subsection{Transformation of the religious worldview of the Evenki:}

\section{traditional and modern understanding}

During the development of the Evenki ethnos, their worldview was formed on the basis of the unity of man and the world around him. The world perception of the Evenki, according to researchers, is connected with the "teaching about a house or a dwelling", according to which nature (rivers, lakes, taiga and sky) is their native dwelling. This dwelling is inhabited not only by people, but also by trees and grass, animals and birds, and most importantly, all sorts of spirits that protect people from 
life hardships and anguishes of body and soul (Vasilevich, 1969). For many years of their existence in harmony with nature, the Evenki have developed a whole system of beliefs that regulate their relationship with nature.

According to traditional Evenk ideas, the Universe consists of three worlds: the upper (Ugu Buga), the middle (Doolin Buga), the lower (Hergu Buga). The upper world was located at sunrise, the lower at sunset. The upper and lower worlds are inaccessible to ordinary people and are inhabited by spirit gods. One of the main deities is Seveki spirit, whose function is the creator of all living things. The spirit of Enekan Buga monitors the life of people and animals, periodically visiting the earth. His assistant, Enekan Togo, is a spirit of fire living in a home. Through fire, the Evenki address spirits. In traditional Evenk beliefs, there is a prototype of the "devil", the evil spirit of Kharga or Avakha (Avai), the owner of the lower earth, or dungeons. The Evenki animate not only all living things, but also all natural phenomena, for example, thunder and lightning are called "agdy" (Vasilevich, 1969). Another important deity of the Evenki is the spirit of the hunt. Each family has its own protective charms and amulets to save the livestock of deer and hunting luck, which are called "Sevekichan" and "Barelak". One significant feature of the Evenki is that the supreme deities can be both male gods and female goddesses.

The main link between people and spirits is a special priest, or a shaman. Shamanism is the ritual side of animism, which aims at communication between people and spirits in order to win their favour, cause desired and neutralize harmful actions (Togulokov, 1960). It is believed that the word "shaman" has Evenki roots and comes from the word "shamangir" (Baskakov, 1966). Scientists suggest that the word "shaman" is of Old Indian origin. G.F. Miller believed that the Samanean religious sect that existed in the ancient India was expelled by the dominant sect of the Brahmins and got disseminated throughout the northern countries and from there came to Siberia, where shamanism was born (Miller, 1937). It is difficult to say how it happened, because shamanism, as the animistic worldview of primitive people, can arise on its own.

It is known that almost no religious ceremony could do without a shaman. The Evenk rites were formed on the basis of a close relationship with the natural environment at the expense of hunting, and later reindeer breeding. Over time, reindeer breeding started to determine the lives of the Evenki. The rite of burial has its own characteristics. The Evenki believe that after death everything turns upside down, therefore during the burial they put broken things in a coffin: a pipe, a bow, arrows, 
household items, decorations. When the Russians came to the region, the dead were buried in the ground, in wooden boxes.

With the development of shamanism, ideas about good and evil spirits, i. e. shaman helpers (seven, heven) populating the earth, started to appear. With the help of the seven, the shaman defended members of his clan. "Helpers" are everywhere: in the air, in the water, on land. After the death of the shaman, his spirits went away with his soul. The shamanic gift could be inherited in each family, both in the next generation and in a generation, from men to women, and vice versa. Assistant spirits of the previous shaman (Vasilevich, 1969) also "came along" with the gift.

In the Evenk beliefs, the cult of animals occupies a special place. There are many animals and birds that the Evenki worship. The wolf is a sacred animal, it was not hunted for. The raven sends earthly messages to the gods. Since the ravens knew how to talk, they were considered to be the souls of men clothed in birdlike appearance (Togulokov, 1960). Observing similarities in the structure of limbs of a bear and a man, the ancient Evenki came to the conclusion that the bear used to be a man. Some Evenki believe that people differ from bears by narrow-shaped eyes, which is why they were called "Evenki Esachi," that is, "cross-eyed". The bear was considered the father of the Evenki, who in ancient times married a woman who gave life to the people. The animal was called "amaka", i. e. "grandfather". When they were hunting for a bear, they did not take the blame killing it, they cut out faces in trees, pointing at them and saying, "It was not me who killed, it was him" (Anisimov, 1950). Killing a bear was accompanied by a patrimonial gathering, calling for a shaman, a general holiday.

Since the times when the Russians started to explore Siberia, various missionary Christian delegations have come to these regions. Orthodox missionaries were one of the first to Christianise the Evenki people, but the Evenk Orthodoxy was nominal, limited to only formal performance of rites. At the same time, the images of Orthodox saints intertwined with ancient spirits (for example, St. Nicholas turned into a friend of the host spirit of the upper world).

Thus, by the beginning of our century, the Evenki possessed the remnants of various stages of development of religious ideas. The most ancient ones include: the animation of all phenomena of nature and everyday life; the idea of the upper and lower worlds as our land; totemism. Later, shamanism appeared. The ideas about the spirits-helpers appeared. A cosmogony with the world of the dead was created. New rituals appeared: seeing the soul of the deceased, cleansing the hunters, initiation of a reindeer and many rituals associated with "treatment" and fight against hostile spirits. 
All this shows how harmonious the Evenki people are with the surrounding world and its inhabitants. Even the influence of Christianity, one way or another, could not change the Evenk world perception.

It can be said that currently the traditions in the life of the Evenki are also preserved. During the expedition of 2017 to the village of Tura, it was noticed that many Evenki still have admiration for spirits, especially fire ones. Many respondents in their interviews mentioned that they needed to feed the fire with fat before they set out on their way and upon arrival. I. A. Vaishnoraite told about sudden weather changes on the day of the hike when she and her friends forgot to feed the fire. People also ask their family to feed the fire, if they are going on a trip.

People talk unwillingly about shamans. They existed and that is all about it. However, sometimes in the course of conversation it was possible to learn some stories related to objects belonging to shamans. The majority of respondents say that these objects are still considered to be the objects of worship, and it can be harmful to touch them. Even the staff of the local lore museum try not to interact with the things of the shamans from the collection, because after that, they say they have a headache.

\subsection{National and religious component in education and enlightenment} in 1930-1990 in the Evenk Municipal District of the Krasnoyarsk Krai (on the material of analysis of the Evenk Archive's documents)

We met the information on religion only twice, in the extreme points of the considered historical period: the 1930s and the 1980s.

1932 is the year when national districts were established. "Resolution No.9 of the Extended Plenum of the Committee of the North following the report of the PCE (People's Commissariat of Education) of the RSFSR "On the next tasks of cultural development in the Far North", 1932 (277 pages)" presents a draft curriculum for district six-month courses on training Soviet teachers to work in the conditions of the Far North. The document has a separate text (from April 9, 1932) devoted to antireligious propaganda as part of the antireligious campaign from April 10 to May 10, 1932. Since this campaign took place in the fourth year of the five-year plan, it should have been "subordinated to the next tasks of social development" and free religious workers from the reactionary influence of religion". According to the content of the text, religious activity was understood as an ideology of exploiting classes, seeking to "push through" their ideas under the guise of the activity of religious organizations as creators and keepers of cultural values. Propaganda was supposed to contribute 
to "exposing Orthodox missionary activity and the activities of the Russian clergy among small-numbered nations, as the political agents of the tsarist government (in the past) and the remnants of capitalist elements (in the present)." The antireligious campaign concerned not only the Orthodox, but also the Muslim, Jewish, and Buryat religions. The Tatars were forbidden to celebrate "Kuiban Bairam", as well as the Jews were forbidden to celebrate "the Jewish Easter" and the Buryats were no allowed to celebrate "nam-murola (?')". These actions were undertaken in anticipation of the wide celebration of May $1^{\text {st }}$ and the "implementation and further deployment of godless international education among children and adults". Antireligious work was systematic and scheduled among preschoolers, schoolchildren and their parents. The control of its implementation was especially intensified during the days of fasting and religious holidays (absenteeism at school, collective farms and work was unacceptable), agitating residents to participate in cultural and political campaigns. The archive document records the fact that in the 1930s there was fundraising for the submarine "Militant Atheist". Thus, the subject of disclosure sounded everywhere and was performed via various types and forms of activity: reports, lectures, lectures with light paintings, antireligious exhibitions, quizzes, question and answer evenings, artistic performances, plays, evenings of revealing "miracles" (chemical and physical experiments), evenings of celebrating achievements, wall newspapers, newspaper antireligious shows. All measures were aimed at mobilizing the masses "to fight religion, and believers to betray their religion". The "Guidelines on educational activities", 1933 (207 sheets) contain information about starting "cultural development among the small-numbered peoples of the Far North", during which a common national culture (among the nationalities of the RSFSR) and the northern culture (culture of minor ethnic groups of the Far North) were developed. The document on the meeting on cultural development dated July 13, 1932, lists the names of the main reports: the second five-year plan of cultural construction in the High North; general education in the North; indigenization of the school of the Far North (writing, textbooks and teaching aids, training and advanced training of teaching staff); the struggle for the quality of the school's performance in the Far North; antireligious work in the schools of the Far North; children's movements and children's self-government of students in the schools of the Far North; the state and tasks of political education among the small-numbered peoples of the Far North. Thus, the document "Standard Provision" (approved by the Deputy Head of the

The name of the holiday in the text of the archival document is written unclearly. It seems that this holiday is not celebrated anymore by the Buryats. 
People's Commissariat on February 24, 1938) provides details on the tasks of political education: clarification of the national policy of the Soviet government; the policy of peace pursued by the Soviet authorities, antireligious work ("combating healers and shamanism, explaining the social essence of the latter, the destruction of religious ideas through conversations about the universe, the origin of man and other natural science issues"). The "Guidelines for methodological work", "the Evenk Department of National Education", 1933 (on 311 sheets) preserved the ten-page document "Antireligious work among the peoples of the Far North" dated August 01, 1933 from the "Antireligioznik" magazine sent by the People's Commissariat for the Enlightenment to help northern teachers in order to guide them in matters of antireligious work. That article was based on the materials of Professor Tan-Bogoraz (V.G. Bogoraz, ethnocultural researcher and linguist of northern languages). etc. In the text, shamanism was determined as a religious prejudice and shamans as local exploiters of the population for their own incomes, animism (worship of spirits) as a world view, "grown out of the powerlessness of the peoples of the North in their struggle with nature, on the basis of the exploitation of kulaks and shamans, still remains in the consciousness of the workers of the North". Several stories and cases where the activity of a shaman is understood as undeniable facts of resistance to socialism under construction are considered in detail. Thus, in the 1930s to implement the concept of cultural development in the Far North, the subject of religion was rooted out.

The archival document of the following decades do not contain a single mention about religion. In the 1940s and 1950s a tremendous work was performed to eliminate illiteracy among the population, educational programmes and general education were introduced. In the 1960s the work on the creation of detailed curricula for each class of regional schools begins, indicating the types of work with students, lists of names of literature pieces for reading. In the 1970s with the active support of the North's school sector, the research institutes of national schools addressed the issue of adult education, encouraging young people to enter technical schools and universities, with a general transition to secondary (seven-year) school education.

Only in the 1980s the field of education faces the problem of learning the native language, its ignorance by the majority of students. The study of the Evenki language becomes a school subject, the methodical guide "A book for a teacher of the Evenki elementary school" for teachers is published. The "Information on measures to improve the activities of public education institutions for 1986-1990, sent to the district committee of the CPSU, 1986" (on 5 pages) states that the issues of the revival of the 
national school and the development of a national school model (Evenk, Yakutsk), are extremely relevant. Experts of the district educational department raise questions about the revival of the practical implementation of the experience of the native language teaching, acquaintance with national applied crafts, studying the subjects of the artistic and aesthetic block, learning practical basic skills in farming, renting reindeer pastures for observation. There was a proposal about the necessity to attract parents' attention to the problems of upbringing and education of children and, in order to help "to introduce subjects with a national-religious component, improve pupils' learning of the native language, consolidate supervision by their native language inspector in their area, define the national-religious component". Thus, only in the late 1980s the issues of the revival of the Evenki language and religious world view with the aim of familiarizing with the northern culture was seriously considered.

\subsection{Religious worldview in artistic culture works of the Evenki}

\subsubsection{Folklore}

The culture of the northern people is, above all, a reflection of its spiritual world, which has been attracting the attention of representatives of other civilizations for a long period of time.

Folklore plays an important role in the everyday life of the Evenki people. It has a special connection to magic and rituals. Adoration of natural forces is reflected in rituals, fairy tales and songs.

Song culture is the most significant part in the tradition of the musical folklore of the North, since the whole life of the nation is connected with it. The songs glorify the beauty of the native nature, life and lifestyle, memories of the past. The basic principle of performance is improvisation, a kind of spontaneous songs created in the process of communicating with the listener.

If we consider the musical creativity of the Evenki as a whole, we can distinguish two layers of music. The first includes songs in the sound volume of fourths or fifths. As a rule, these are "zaklichki", "hunting tunes", "travelling improvisations". The second layer of music includes songs in the range of the sixth and octave intervals. In them one can hear chromaticisms, a complex melodic line: lyrical and humorous songs, crying, shamanic spells. The abundance of grace notes, complex rhythmic organization, as well as the presence of throat sonority in singing is a feature of their musical culture.

The Evenki subdivide the songs into the following types: "iken" is an improvisation song performed at competitions of hunters and warriors; "davlavun" is a translated 
song (borrowed from neighbours), as a rule, having a non-Evenk style; "tagivka" is a mystery song; "nimnakan" is a heroic tale, a legend; "ulgur" is stories about different cases (recent events); "erivun" is a shaman song appealing to spirits-helpers (the words in these songs cannot be translated, most often they have two or three syllables) (Vasilevich, 1969).

The musical language in shamanism is represented by a system of expressive means that have certain semantic properties that allow the shaman to safely reunite with the supernatural world. Singing in such acts is recitative and declarative. During the ritual, the shaman changes the tone value depending on their inner emotional state, and the specific throaty-wheezing sounds give a special sound to the religious shaman melodies. It is very difficult to record such singing on a staff, since two or several sounds are heard at the same time, i. e. a sound cluster. The basic type of performance is ostinato rhythmic organization of the spoken text and instrumental accompaniment.

A tambourine is of particular importance in shamanism, since it is an integral part of a religious ceremony. The Evenk tambourine differs significantly from the traditional percussion instrument. It is made of elk leather and has an oval shape. The sound it produces often gives a ratio of fourths and fifths (for example, G-D-G). It should be also noted that the performing practice of the shaman is associated not only with the ceremonial action and ritual chants. They are also skilful storytellers, dancers and singers of lyric melodies.

\subsubsection{Graphics and painting}

The following groups of religious works were chosen for the philosophical and art analysis of graphic and painting works by the Evenk artists:

1) landscape paintings;

2) graphic works and paintings, whose art image reflects the motives of shamanism;

3) graphic works and paintings, whose art image reflects the motives of Christianity.

The first group is represented by landscape paintings. The objects of landscape images in the works of the Evenk artists are various parts of the North (Fig. 1). At the same time the authors often do not indicate the exact geography of the depicted area in the title of the picture, preferring the name associated with the time of the year or time of the day. Representatives of this group are landscapes "Golden Autumn" (1983), "December at Uksili" (1993) by S.I. Kazantsev, "Morning in the Taiga", "Spring", "Forest Lake" by B.B. Romanovsky, "Pink Sunset" (1981), "Evening" (1982), "Morning by the River" (1998), "Morning Freshness" (2007) by V.V. Startsev. 
The levelling of the specific depicted terrain expands the artistic idea of the masters. is It is not a specific area that matters, whose name would fix certain boundaries, but the whole Evenki nature in its globality and unity. It is not by chance that landscape paintings by the Evenk artists encourage the viewer to look beyond the picture.

Often, genre elements are introduced into the artistic space of landscapes (the image of a man, a deer, a house). These sign-symbolic forms in most works occupy an insignificant part of the canvas, thus expressing the idea of the power of nature and the existence of man and animals in it as part of this world. Thus, nature for the Evenki is the personification of the supreme power that governs not only the phenomena of nature, but also the process of hunting, which is the basis of the existence of the Evenki people.

The second group of works, whose symbolic forms embody the traditional religious worldview of the Evenki, are religious paintings. The basis of the artistic image of these works are motives associated with the national religion, i. e. shamanism. This group is represented by "The Shaman" by V.I. Donchenko and "Kamlaniye" (2004) E.S. Vishnevskaya (Fig. 2-3).

The symbolic forms of the work by V.I. Donchenko represent the shaman as a server of a religious cult, who is special in his physical and spiritual essence. Through symbolic signs, a human image is filled with a more complex content. The arms outstretched to the sides are depicted by means of elongated triangular shapes that

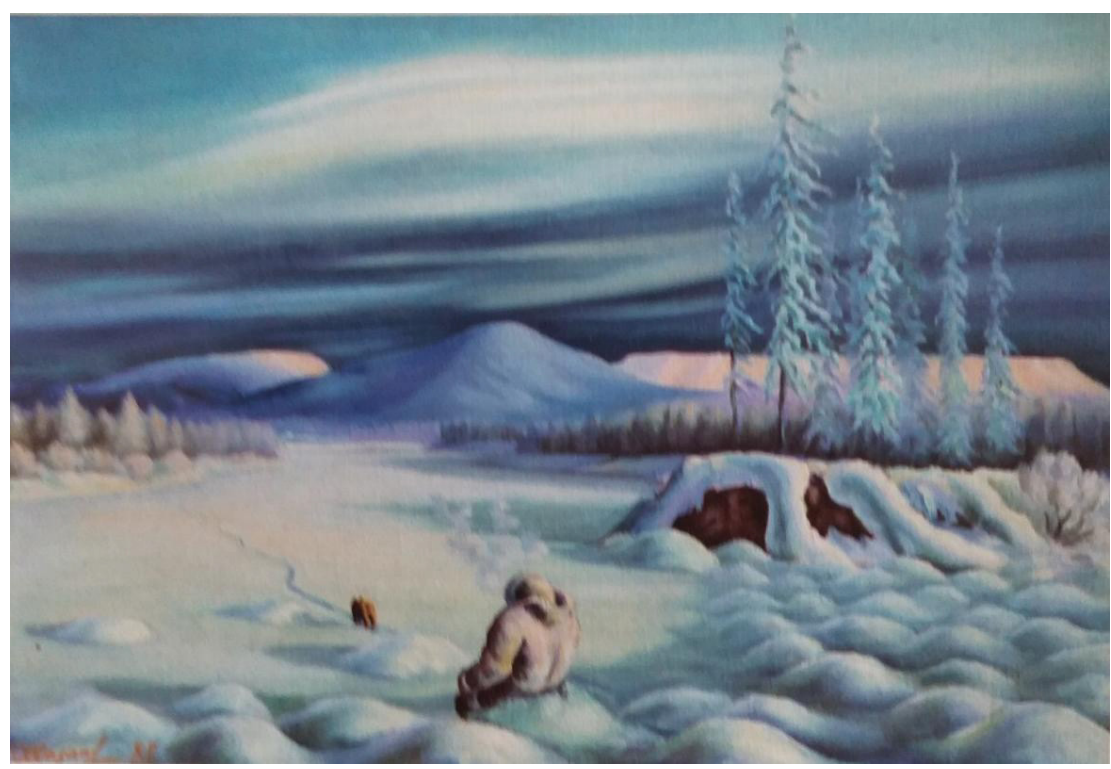

Fig. 1. Kazantsev S.I. The breath of the North. Oil on canvas, 56 x 80. 1986 


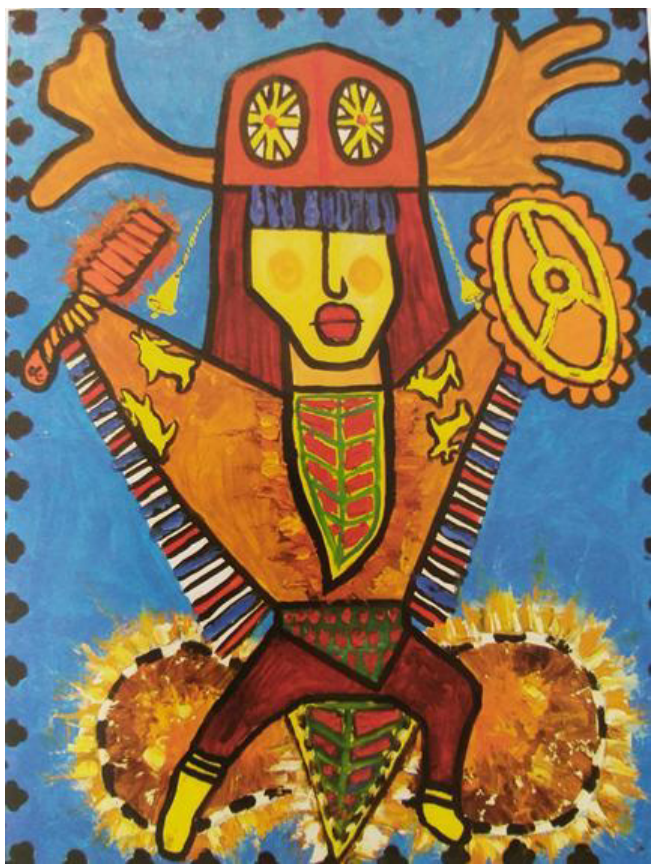

Fig. 2. Donchenko V.I. The Shaman. Paint. $80 \times 60$

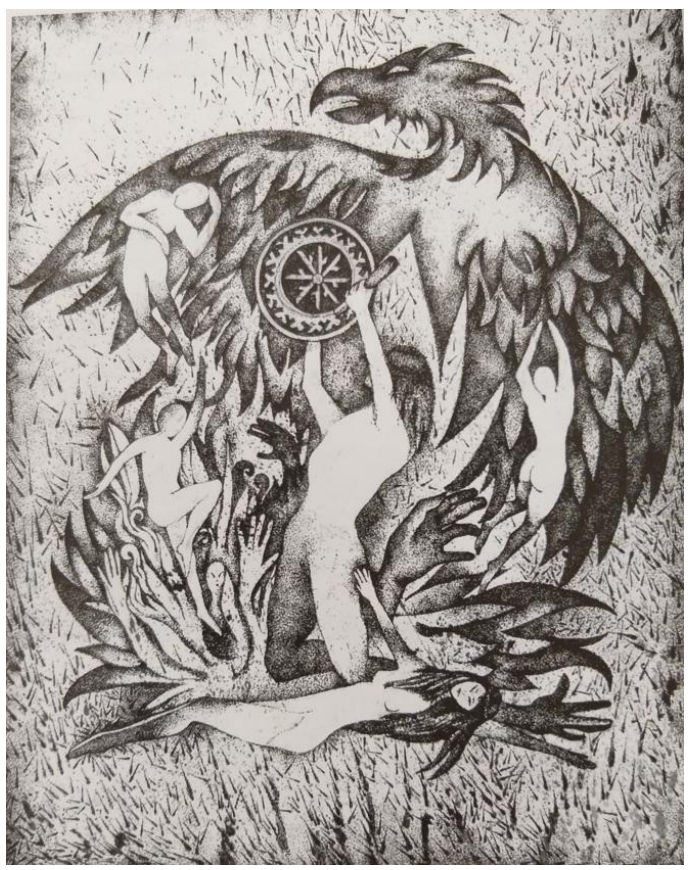

Fig. 3. Vishnevskaya E.S. Kamlaniye. Paper, ink, 39 x 30.2004

remind of the open wings of a bird. A number of such signs as the horns on the shaman's head, animal and solar signs on the "hands" and the headdress, a disproportionate figure of the character with pointedly exaggerated proportions of the head and body, absence of eyes on the face, give the shaman special features not typical for other people. The human image becomes a sign of a container for spirits-helpers, without which shamanism is impossible. According to A.F. Anisimov, the Evenki believed that the ancestor spirits reorganize the shaman's body and soul for kamlaniye, they "... substitute the natural by the supernatural, remove all unnecessary parts and provide the missing ones, make the body hard like iron, harden it in fire, etc." (Anisimov, 1958: 190).

In the graphic work by E.S. Vishnevskaya "Kamlaniye", the process of the shaman's metamorphosis becomes important. The central figure with raised arms sets the compositional axis that encourages the viewer to look in the upper part of the picture. The impersonal human silhouettes surrounding this figure echo the given movement upwards. The smoothness of the lines of the silhouettes is similar to the feathers of the bird's opened wings, against the background of which human-like characters are depicted. By means of the given upward movement and smoothness of lines, the image of a tambourine in the hands of the central figure, a bird sign, a visual 
concept of flight is formed. Kamlaniye, therefore, becomes the process of the flight of the religious server's soul to the upper world. The mediator in this movement is the bird, whose curved beak and wide spread wings resemble an eagle, one of the birds, which shamanic spirits-helpers incarnate in, according to the Evenk religious concept.

A separate group of graphic works and paintings of the Evenk artists consists of works that visualize the motives of Christianity. This group is represented by "Madonna" (2008) by E.S. Vishnevskaya, "Evenki Madonna" by S.G. Salatkin and "Mother" V.P. Vlasov (2002) (Fig. 4-5). If the composition "Madonna" by E.S. Vishnevskaya is built exclusively on the basis of the "Tenderness" iconographic scheme typical for the Russian icon-painting tradition, in the works of S. G. Salatkin "Evenki Madonna" and V.P. Vlasov "Mother" the motives of Christianity are traced not in the depicted visual signs, but in the artistic idea of the works.

The symbolic forms of the paintings of S.G. Salatkin and V.P. Vlasov embody the idea of the value of the woman as a guardian of the family, the mother of her children, of what lies at the heart of the Christian worldview.

Therefore, the analysis of the symbolic forms of graphic works and paintings of the Evenk artists expressing the religious picture of the world showed the importance of such values as:

- honouring the nature surrounding the Evenki (the embodiment of the memory of the ancient Evenk beliefs);

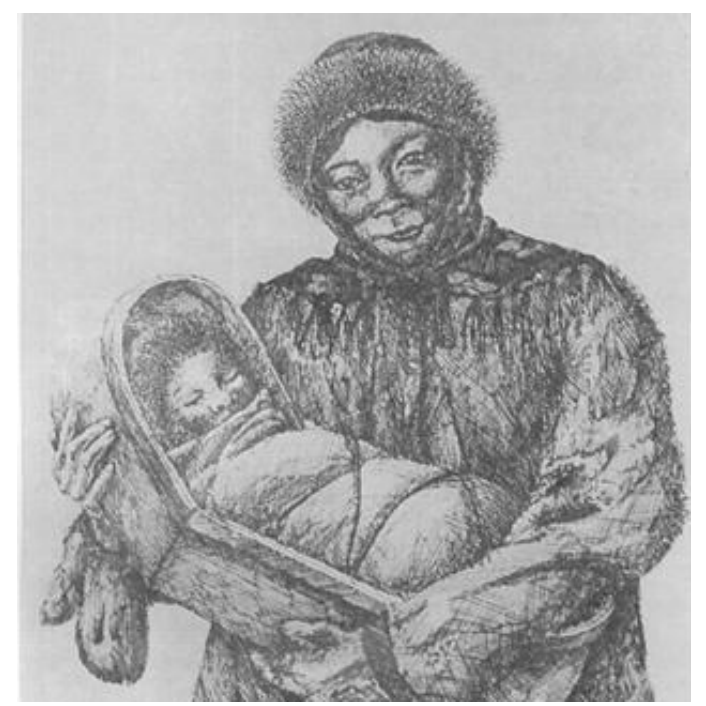

Fig. 4. Salatkin S.G. Evenki Madonna. Whatman paper, ink, quill

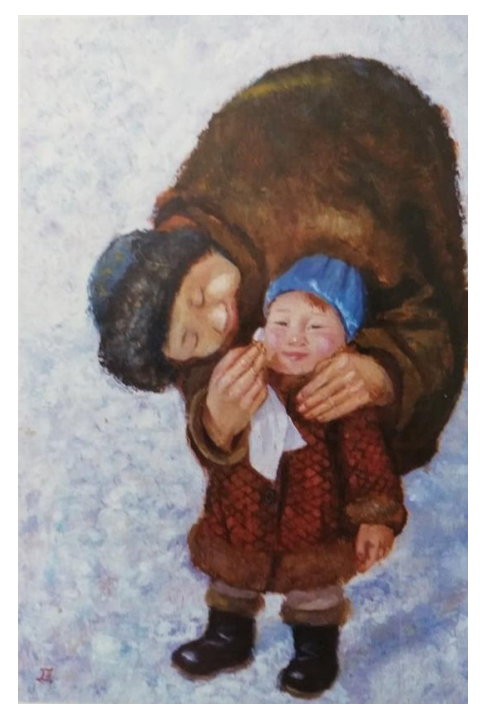

Fig. 5. Vlasov V.P. Mother. Oil on canvas, $84 \times 57.2002$ 
- religious and mythological understanding of the complex metamorphosis happening to the shaman in the process of their transition from one world to another;

- a special attitude to the woman as a guardian of the family hearth, the mother of her children, providing the link between generations (the embodiment of the motives of Christianity).

After analysing the visual images of the works by the artists of the Evenk school, we can conclude that in the Evenki's religious picture of the world, the memory of the ancient traditional beliefs is strong. At the same time, the symbolic forms of the art works by the Evenk artists embody the traditions of Christianity. These traditions are most pronounced in the works of the 2000s. Perhaps this is due to the increasing prevalence of knowledge about the traditions of Christianity among the Evenki in the 1990s and, on this basis, the adoption of some of them. Therefore, for example, in 1995 in Stockholm, at the Institute for Bible Translation, the Evenki linguistic scholar and folklorist A. Myreyeva translated "Stories about God" into the Evenki language. In 2001, scientists of the same institute translated the Gospel of Luke ("Luke Isustuli Dukunan") into the Evenki language. Thus, the visual images of graphic works and paintings by the masters of the Evenk art school demonstrate a common transformation of the religious worldview among some representatives of the Evenki ethno-cultural group, associated mainly with modern trends of globalization and assimilation.

\subsubsection{Applied and decorative art}

The applied and decorative art of the Evenki embodies the harmony of man and nature.

The main techniques in the decorative and applied art of the Evenki are bone, wood and iron carving, lead and tin casting, making wooden figures, birchbark embossing, wood painting, sewing from fur strips and squares, embroidering with fur and reindeer white under-the-neck fur, beads and silk (Vasilevich, 1969: 203). At the time when there were no beads, they used stones, teeth, horns, and hooves for decoration. Most often these techniques were used to decorate household utensils, clothes and footwear.

The main ornaments were geometric: lines, triangles and arcs. Elements of ornaments have a connection with the world of nature and most often are images of animal parts. Accordingly, the names of the ornaments were given by similarity with the objects: delog ien (horn of a goat), udyakar (traces of animals), heli ien (mammoth's fang), dylacha (sun in the sky), ieker (antlers of a deer), iktemal (white teeth), dyukar (chumiks), sekteker (tree branches), dedomo and udyal (flickering of deer's legs) 
(Saf'iannikova, 2006). Moreover, the images of animals and their body parts were imaged on various forged pendants on shamans' costumes. This is noted not only by researchers (Vasilevich, 1969), but also by the masters themselves (this was said in interviews by S.I. Uvachan and T.M. Saf'iannikova). The researcher I.E. Maksimova notes that the transmission of sensations is typical for northern peoples, therefore there are no repetitive things, all things are unique. Master S. I. Uvachan says that he himself is a reindeer herder and creates his products precisely when he goes into the taiga with the brigade. There they themselves produce all their equipment together, each master is responsible for his own processes, they complement each other with their skills. The setting inspires the craftsmen, determines the decor of the products. The craftswoman V.A. Khutokogir says this about ornaments: "I make what I saw. I sew what comes to my mind".

The ornament of an ethnic costume still has a protective function: as the Evenk masters explain, clothes are decorated at the edges, bottom and tail. The Evenki still preserve the tradition of careful decoration of burials (Evenki: khallasik) and wedding seasonings, wedding gifts (dilachakan, kumalan). The seams are carefully sealed and sometimes covered with a strip of fabric to prevent the penetration of any evil spirits, that is, unpredictable spirits from the Lower World (Kistova, Pimenova, 2017).

Different colours were used: black, white, yellow, green, red. Often there is an alternation of dark and light, for example, in embroidery of beaded strips of black and white colour, in a fur mosaic.

The main objects of decorative and applied art used by the Evenki today are mainly deer fur products and clothing: traditional carpets — kumalans, bags — potakui, heavy beaded bibs from reindeer skin — helmi, nel, zipuns — hipun, sipun, traditional Evenk bag — inmek, parka — hegilme, ogdoko, men's bib — helmi, women's bib — nelmi, nelken. The bottom of the sleeves, the bottom of clothing, neck hole, waist cloth are carefully decorated: embroidered with beads, fringe of deer fur, stripes of coloured fabric on the cloth.

Researchers also note the interpenetration of various traditions in the ornaments of northern peoples (Vasilevich, 1969). The key keeper of the Evenki Local Lore Museum I. A. Vaishnoraite also notes this. The researcher I E. Maksimova in her interview notes that it is difficult to say how authentic the contemporary works are, there is a constant change and inclusion of new elements. New materials mean new elements. The form does not change, it is important and convenient for the Evenki, but the ornaments are updated. 
It can be said that traditional clothes, richly decorated with ornaments, have a special meaning nowadays, showing the status of a person in the world. It is ordered for celebrations in order to show oneself and express belonging to the Evenki people. I.A. Vaishnoraite connects traditional decorative and applied art mainly with the manufacture and decoration of clothes. She says that with the development of the country and the region, only the focus of decorative and applied art has changed, stylization of traditional culture has appeared, some areas of arts and crafts and craftsmanship have been lost. Clothes and footwear are made mainly for beauty, less often they have any functional value. Today, the most popular traditional product is footwear - mukluks.

Many masters and experts note that ornaments nowadays do not carry sacral meaning, but are rather decorative copying. An employee of the Evenki Local Lore Museum G.K. Lapuko in her interview noted that today traditional types of decorative and applied art are being lost. Fur dressing and creation of commercial items is rare. Modern materials are replacing traditional materials, but they evoke thoughts about the stylization of traditional art rather than its development. She says that the only trend in the Evenk decorative and applied art, which has not lost its popularity, is beadwork. Nevertheless, even this craft is undergoing changes, it becomes more ordinary. Patterns and ornaments lose their original meaning, a lot of new, alien signs and symbols borrowed from other cultures appear in them. "Previously, there was a leg of a razorbill, it had some meaning. This one here is a triangle, or even deer's antlers, it used to be everywhere traditionally. Now there are so many patterns, so many things. It happens that some may not pay attention to them. It is not meaningful. If only to adopt this pattern on clothing or pattern. But it is not so important now. It will not carry its sacredness".

Let us also look at the traditional rugs, kumalans, as an example. They are still used by the Evenki, they decorate homes and cars. The traditional kumalan resembles sand clock or bow - a rectangular shape with rounded edges tapering towards the centre, where it is tied with a string of beads. This form refers to duality of the world, the Upper and Lower worlds.

Round kumalans are also quite common, representing the image of the sun, which was sacred for the Evenki. It is interesting that in the Evenki Local Lore Museum, there is an example of kumalan with a portrait of V.I. Lenin in orange tones. This can serve as an example of the transformation of the picture of the world, with the advent of the Soviet power.

The religious worldview is clearly reflected in the art and crafts of the Evenki through ornamental patterns. They all show the close connection of the Evenki with 
the natural world around them. Despite the fact that in modern times, according to masters and experts, these patterns have lost their sacral meaning, nevertheless, the memory of the people retains what these ornaments stand for.

\section{Conclusion}

Analysis of the transformation of religion's role in the preservation of the Evenki's traditional way of life in the period from 1930s to 2000s in the northern regions of the Krasnoyarsk Krai, as well as its reflection in the education system and traditional culture showed that by the beginning of the $21^{\text {st }}$ century the Evenk culture included remnants of different stages of religious ideas' development. The current state of religious trends in culture, education and everyday life of the Evenki indicates that there are prerequisites for the interpretation of traditional religious cults taking into account world religions (Christianity, Islam, Buddhism), where the key ideological message is maximum harmonization of relations with the environment. At the same time, one should note the loss of the original sacred meaning by many traditional household items and works of art, i. e. their religious "simplification".

\section{References}

Anisimov, A.F. (1950). Kul't medvedia u evenkov i problema evoliutsii totemicheskikh verovanii [The cult of the bear among the Evenks and the problem of the evolution of totemic beliefs]. In: Voprosy istorii religii $i$ ateizma [Questions of the history of religion and atheism]. Moscow, 303-323.

Anisimov, A.F. (1958). Religiya ehvenkov v istoriko-geneticheskom izuchenii $i$ problemy proiskhozhdeniya pervobytnyh verovanij [Religion of the Evenks in historical genetic studies and the problems of the origin of primitive beliefs]. MoscowLeningrad, Akademiya nauk, 236 p.

Baskakov, N.A. (1960). Tyiurkskie iazyki [Turkic languages]. Moscow, Izdatel'stvo vostochnoi literatury, $248 \mathrm{p}$.

Bazanov, A.G., Kazanskiy, N.G. (1939). Shkola na Kraynem Severe [School in the Far North]. Leningrad, Uchpedgiz, 205 p.

Bogoraz, V.G. (1939). Chukchi. Part 2 [Chukchi]. Leningrad, Institute of the Peoples of the North CEC of the USSR, 214 p.

Brandišauskas, D. (2018). The gluttons of eastern Siberia. Spirits, poachers, and cannibals in Evenki perceptions. In: Études mongoles et sibériennes, centrasiatiques et tibétaines, (49), 22 p., DOI: 10.4000/emscat.3441 
Chumak, E.G. (2008). Osnovnye meropriiatiia gosudarstvennoi obrazovatel'noi politiki v otnoshenii korennogo naseleniia Severa v 20-50-e gg. XX v. [The main activities of the state educational policy in relation to the indigenous population of the North in the 20-50s of the 20 $0^{\text {th }}$ century]. In: Vestnik arkheologii, antropologii $i$ etnografii [Bulletin of archeology, anthropology and ethnography], (8), 109-114.

Cox, J.L. (2016). From Primitive to Indigenous. The Academic Study of Indigenous Religions. Routledge, 206 p.

Gashilova, L.B. \& Nabok, A.A. (2012). Etnoregional'noe obrazovanie na Severe: puti razvitiia i modernizatsii [Ethno-regional education in the North: ways of development and modernization]. In: Sovremennoe sostoianie i puti razvitiia korennykh malochislennykh narodov Severa, Sibiri i Dal'nego Vostoka [Modern state and ways of development of indigenous small-numbered peoples of the North, Siberia and the Far East]. Moscow, Russian Federation Council, 191 p.

Geertz, A.W. (2017). Religion and Community in Indigenous Contexts. In: Religion: Empirical Studies. London, Routledge, 328 p.

Gorelikov, A.I. (2015). Natsional'naia politika v otnoshenii korennykh malochislennykh narodov Dal'nego Vostoka v poslevoennyi period (1945-1950kh gg.) [National policy in relation to the indigenous small-numbered peoples of the Far East after the WWII (1945 — first half of the 1950s)]. In: Teoriia i praktika obshchestvennogo razvitiia [Theory and practice of the public development], (7), 136-138.

Hudozhniki zemli Evenkijskoj: narodnoe tvorchestvo EHvenkii: al'bom [Artists of the Land of Evenk: Evenkii folk art]. (2010). Otd. kul'tury adm. EHvenk. municip. r-na, Municip. uchrezhdenie kul'tury “EHvenk. kul't.-dosug. Centr”. Krasnoyarsk, Centrosib, 55 p.

Kistova, A.V., Pimenova, N.N. (2017). Current Condition of Decorative and Applied Art of the Indigenous Peoples Resident in the Territory of the Evenki and Taymyr Municipal Districts (Economic and Sociocultural Practices). In: Journal of Siberian Federal University. Humanities \& Social Sciences. (10), 1485-1506.

Koptseva, N.P., Reznikova, K.V., Pimenova, N.N., Sitnikova, A.A., Bahtina, I.A. (2018). Doroga k solncu: skazki [Road to the sun: fairy tales]. Krasnoyarsk, Sibirskij federal'nyj universitet, $192 \mathrm{p}$.

Koptseva, N.P. (2017). Dekorativno-prikladnoe iskusstvo korennykh malochislennykh narodov Krasnoiarskogo kraia. Polevye issledovaniia. [Decorative and Applied Art of the Indigenous Peoples of Krasoyarsk region. Field studies]. Izdatel'skie resheniia, 128 p. 
Koptseva, N.P., Zamaraeva, Iu.S., Sergeeva, N.A., Fil'ko, A.I., Strucheva, E.S., Kirko, V.I. (2018). Polevye issledovaniia v evenkiiskom munitsipal'nom raione po materialam nauchno-issledovatel'skoi raboty [Field studies in the Evenk municipal district based on research materials]. Krasnoiarsk, Krasnoyarskiy gosudarstvennyi pedagogicheskii universitet im. V.P. Astaf'eva, 210 p.

Kudashkin, V.A. (2013). Protsess akkul'turatsii u korennykh malochislennykh narodov Vostochnoi Sibiri v usloviiakh sovetskoi sistemy v 1920-1980-e gg. [The process of cultural assimilation among indigenous small-numbered peoples of the Eastern Siberia in the conditions of the Soviet system in 1920s-1980s]. In: Istoricheskie, filosofskie, politicheskie $i$ iuridicheskie nauki, kul'turologiia $i$ iskusstvovedenie. Voprosy teorii $i$ praktiki [Historical, philosophic, political and judicial sciences, cultural and art studies], 2 (3), 102-105.

Literatura narodov Severa [Literature of the peoples of the North] (2002). SaintPetersburg, Publishing house of Herzen University].

Miller, G.F. (1937). Istoriia Sibiri. [History of Siberia]. Moscow, Izdatel'stvo AN SSSR, 607 p.

Saf'iannikova, T.M. (2006). Raduga krasok sonkana [The rainbow of colors of Sonkan]. Krasnoiarsk: Sibirskie promysly, 58 p.

Sumakov, V. (1999). Hudozhniki zemli EHvenkijskoj: al'bom [Artists of the Land of Evenk: album]. Toura, b. i., 27 p.

Togulokov, V.A. (1960). Idushchie poperek khrebtov [Across the ridges]. Krasnoiarsk: Krasnoiarskoe knizhnoe izdatel'stvo, 184 p.

Vasilevich, G.M. (1969). Evenki. Istoriko-etnograficheskie ocherki (XVII-XX vv.) [The Evenks. Historical and ethnographic notes (18 $-20^{\text {th }}$ centuries)]. Leningrad, $304 \mathrm{p}$.

Wilson, D.G. (2013). Redefining Shamanisms: Spiritualist Mediums and Other Traditional Shamans as Apprenticeship Outcomes. London, New Delhi, New York, and Sydney, Bloomsbury Press, 254 p.

Zamaraeva, Iu.S., Reznikova, K.V., Pimenova, N.N. (2017). Istoriia antropologicheskikh issledovanii korennykh narodov Sibiri [History of the anthropological studies of the indigenous peoples of Siberia]. In: Sibirskii antropologicheskii zhurnal [Siberian anthropological journal], (1), 6-21.

Zamaraeva, Iu.S. (2018). Experience in the Preservation and Development of the Evenki Language in the Evenki Municipal District of the Krasnoyarsk Krai on the Basis of the Analysis of Evenki Archival Documents. In: Journal of Siberian Federal University. Humanities \& Social Sciences, 11 (8), 1328-1370. 


\title{
Религия эвенков: история и современность
}

\author{
Ю.С. Замараева, В.С. Лузан, С.В. Метляева, \\ Н.Н. Середкина, Н.П. Копцева, \\ А.И. Филько, М.Я. Хребтов
}

Сибирский федеральный университет Россия, 660041, Красноярск, пр. Свободный, 79

В статье предпринята попытка раскрыть трансформацию роли религии в сохранении традиционного образа жизни эвенкийского этноса в период с 1930 по 2000-е годы на территории северных районов Красноярского края, а также ее отражения в системе образования и в традиционной культуре (фольклор, изобразительное искусство, декоративно-прикладное искусство). В статье отмечается, что анализ отечественных и зарубежных исследований культуры и религии эвенков подтверждает обоснованность обращения к междисииплинарному типу исследования. В качестве предмета исследования выступают традиционные и нетрадииионные религиозные течения, воплощенные в культуре и быту эвенкийского этноса. Для решения задач исследования применяются наблюдение, аналитико-описательный метод, включающий анализ отдельных элементов развития традиционной культуры эвенков с последующим обобщением полученных данных, а также сравнительно-исторический и диалектический методы. Кроме того, в числе основных методов исследования активно используется философско-искусствоведческий анализ произведений искусства эвенков различных видов. В заключение обозначены общие выводы и тенденщии, характеризующие современное состояние воплощения религиозных течений в культуре, образовании и быту эвенкийского этноса.

Ключевые слова: Эвенкийский муниципальный район, коренные малочисленные народы Севера, эвенки, религия, фольклор, художественная культура.

Исследование выполнено при поддержке АO «Востсибнефтегаз» в рамках реализащии проекта по выполнению научно-исследовательских работ «Возрождение эвенкийского языка: создание первой иифровой аудиотеки эвенкийского языка».

Научная специальность: 24.00.00 - культурология. 